\title{
Important changes in the timing of influenza epidemics in the WHO European Region over the past 20 years: virological surveillance 1996 to 2016
}

Saverio Caini ${ }^{1}$, François Schellevis ${ }^{1,2}$, Clotilde El-Guerche Séblain ${ }^{3}$, John Paget ${ }^{1}$

1. Netherlands Institute for Health Services Research (NIVEL), Utrecht, The Netherlands

2. Department of General Practice and Elderly Care Medicine, EMGO Institute for Health and Care research, VU University Medical Center, Amsterdam, The Netherlands

3. Sanofi Pasteur, Lyon, France

Correspondence: Saverio Caini (s.caini@nivel.nl)

Caini Saverio, Schellevis François, El-Guerche Séblain Clotilde, Paget John. Important changes in the timing of influenza epidemics in the WHO European Region over the past 20 years: virological surveillance 1996 to 2016. Euro Surveill. 2018;23(1):pii=17-00302. https://doi.org/10.2807/1560-7917.ES.2018.23.1.17-00302

Introduction: The global epidemiology of many infectious diseases is changing, but little attention has been paid to whether the timing of seasonal influenza epidemics changed in recent years. This study investigated whether the timing of the peak of influenza epidemics has changed in countries of the World Health Organization (WHO) European Region between 1996 and 2016. Methods: Surveillance data were obtained from the WHO FluNet database. For each country and season (July to June of the next year), the peak was defined as the week with the highest 3-week moving average for reported cases. Linear regression models were used to test for temporal trends in the timing of the epidemic peak in each country and to determine whether this differed geographically. Results: More than 600,000 influenza cases were included from 38 countries of the WHO European Region. The timing of the epidemic peak changed according to a longitudinal gradient, occurring progressively later in Western Europe (e.g. by 2.8 days/season in Spain) and progressively earlier in Eastern Europe (e.g. by 3.5 days/ season in the Russian Federation). Discussion: These results were confirmed in several sensitivity analyses. Our findings have implications for influenza control and prevention measures in the WHO European Region, for instance for the implementation of influenza vaccination campaigns.

\section{Introduction}

The global epidemiology of many infectious diseases has changed in recent years; a number of concomitant and mostly anthropogenic factors play a role in this process, including climate change, increased urbanisation, population mobility, deforestation, agricultural intensification and forced displacement of human populations [1]. Most research has focused on malaria and other vector-borne infections [2-4] or on and food-and waterborne diseases $[5,6]$. The question of whether the timing of seasonal influenza epidemics has changed in recent years has received comparatively little attention. However, influenza seasonality is known to be linked to many of the above factors [7-12], and the temporal characteristics of influenza epidemics may evolve over time as a result of changes in these factors $[13,14]$.

Seasonal influenza epidemics in the northern hemisphere are typically characterised by a short epidemic period of 8 to 12 weeks that varies in intensity during the winter months (November to March) [15] and are associated with substantial morbidity and mortality. Annual vaccination is the most effective measure to reduce the burden of influenza and is most effective when vaccination campaigns coincide optimally with seasonal epidemics. Considering that 2 to 4 weeks may be required to develop an immune response to the vaccine [16] and protection may wane within 6 months [17], the timing of the epidemic peak is an important element that should be considered to optimise the effectiveness of influenza vaccination campaigns.

To assess whether the epidemiology of influenza has changed in the World Health Organization (WHO) European Region (900 million inhabitants), we examined for each country and the Region as a whole whether the timing of epidemic peaks has changed (i.e. occurs earlier or later) between 1996 and 2016.

\section{Methods}

Data

Influenza virological surveillance data were obtained from the publicly available web-based database FluNet, which is coordinated by the WHO [18]. Information on the weekly number of laboratory-confirmed cases of influenza (overall and by virus type, subtype and lineage) is entered into the FluNet database by the 
Countries where the peak of reported influenza cases has occurred progressively later or earlier, WHO European Region, July 1996-June $2016(\mathrm{n}=53)$

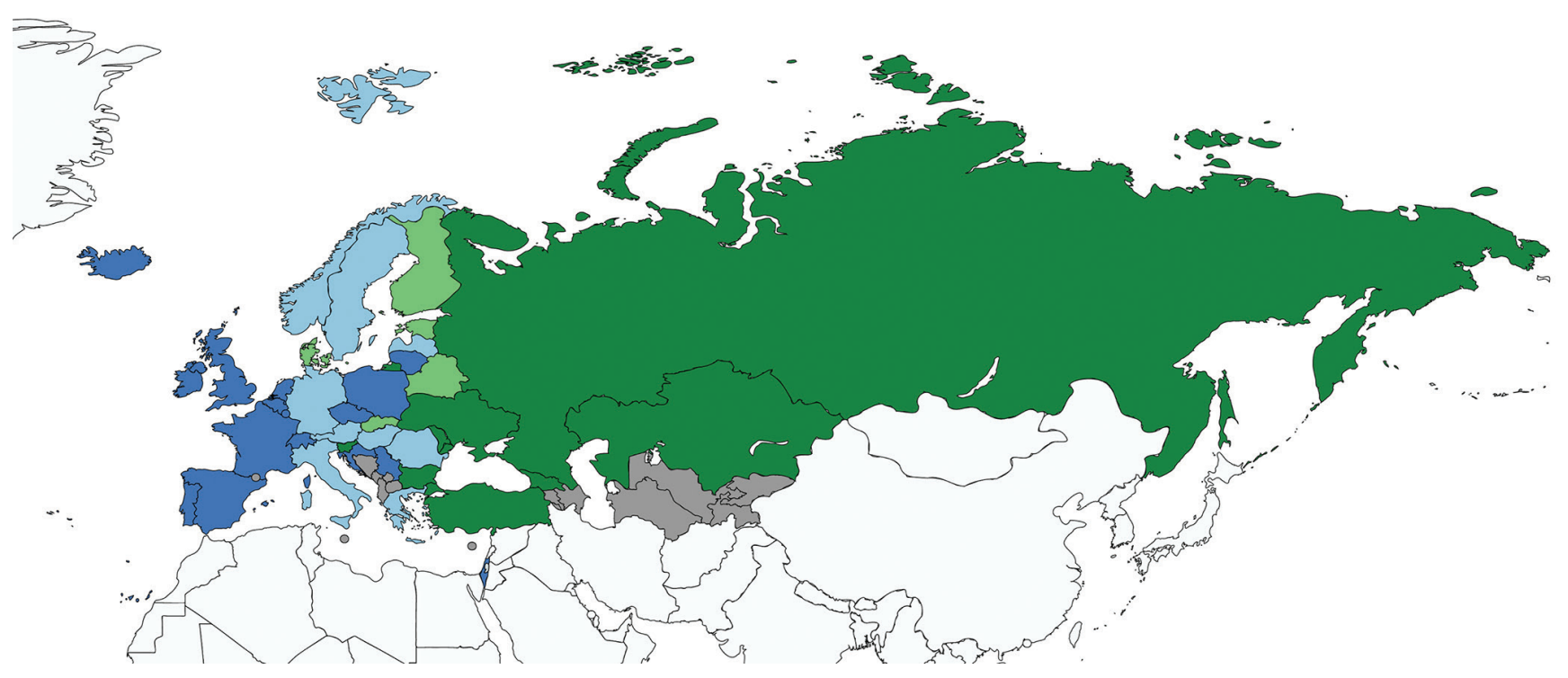

Dark blue: later by $\geq 1$ day every year; light blue: later by o-«1 days every year; dark green: earlier by $\geq 1$ day every year; light green: earlier by 0-২1 days every year, averaged over the study period; grey: countries not included in the analysis.

Source: WHO FluNet database [18] for July 1996 to June 2016. Data for July 2009 to June 2010 were excluded.

national influenza centres and other influenza reference laboratories of 113 countries participating in the Global Influenza Surveillance and Response System. On 6 November 2016, influenza surveillance data were downloaded for the period between week 27/1996 (starting 1 July 1996) and week 26/2016 (starting 27 June 2016), henceforth referred to as the study period, for all 53 countries in the WHO European Region [19]. We excluded from the dataset the 2009/10 influenza season and influenza $\mathrm{A}\left(\mathrm{H}_{1} \mathrm{~N}_{1}\right)$ pdm2009 influenza cases reported between April and June 2009 (for all countries), seasons with fewer than 20 weeks of reporting or fewer than 100 influenza cases overall (only for countries where this applied), and countries that had data for fewer than five influenza seasons.

\section{Definitions}

The unit of analysis was the 'season', which was defined as the period between 1 July of one year and 30 June of the next year. For each country and season, the peak of the influenza epidemic was defined as the week in which the 3 -week moving average of the number of reported influenza cases was highest [20]. Where the peak could not be identified unambiguously, the duration of the moving average was expanded by 2-week increments until the peak could be identified unambiguously. Because a given epidemiological week could start on different days in different years, the week number of the epidemic peak was replaced with the progressive number of the day in a year ( 1 to 365 ) corresponding to the Wednesday of that week.

\section{Statistical analysis}

For each country, linear regression models were used to assess the association between the season (independent variable) and the timing of the peak (dependent variables) (Model 1). A beta coefficient $>0$ indicated that, with each influenza season, the influenza epidemic peak occurred progressively later; a beta coefficient $<0$ indicated the opposite trend.

Linear regression models were then used to assess the association between the geographical coordinates (latitude and longitude) of each country's centroid [21] (independent variables) and the shift in timing of the peak (Model 2). A beta coefficient $>0$ indicated that the shift in timing of the epidemic peak increased moving from east to west (for longitude) or from south to north (for latitude); a beta coefficient $<0$ indicated the opposite trend. For all regression models, the 95\% confidence interval $(\mathrm{Cl})$ for the beta coefficient, the $\mathrm{p}$ value, and the coefficient of determination $\mathrm{R}^{2}$ were calculated. We did not fit random effect meta-analysis models to obtain a summary beta coefficient for the whole WHO European Region analyses because the country-specific beta coefficients (Model 1) were highly heterogeneous owing to a statistically significant relationship with the country longitude (see Results section).

Influenza epidemics tend to spread according to westto-east and (less frequently) south-to-north gradients in the WHO European Region [22]. In order to assess whether the duration of influenza activity in the WHO 


\section{FIGURE 2}

Association between a country's longitude and the country-specific temporal shift of the influenza epidemic peak, WHO European Region, July 1996-June $2016(\mathrm{n}=38)$

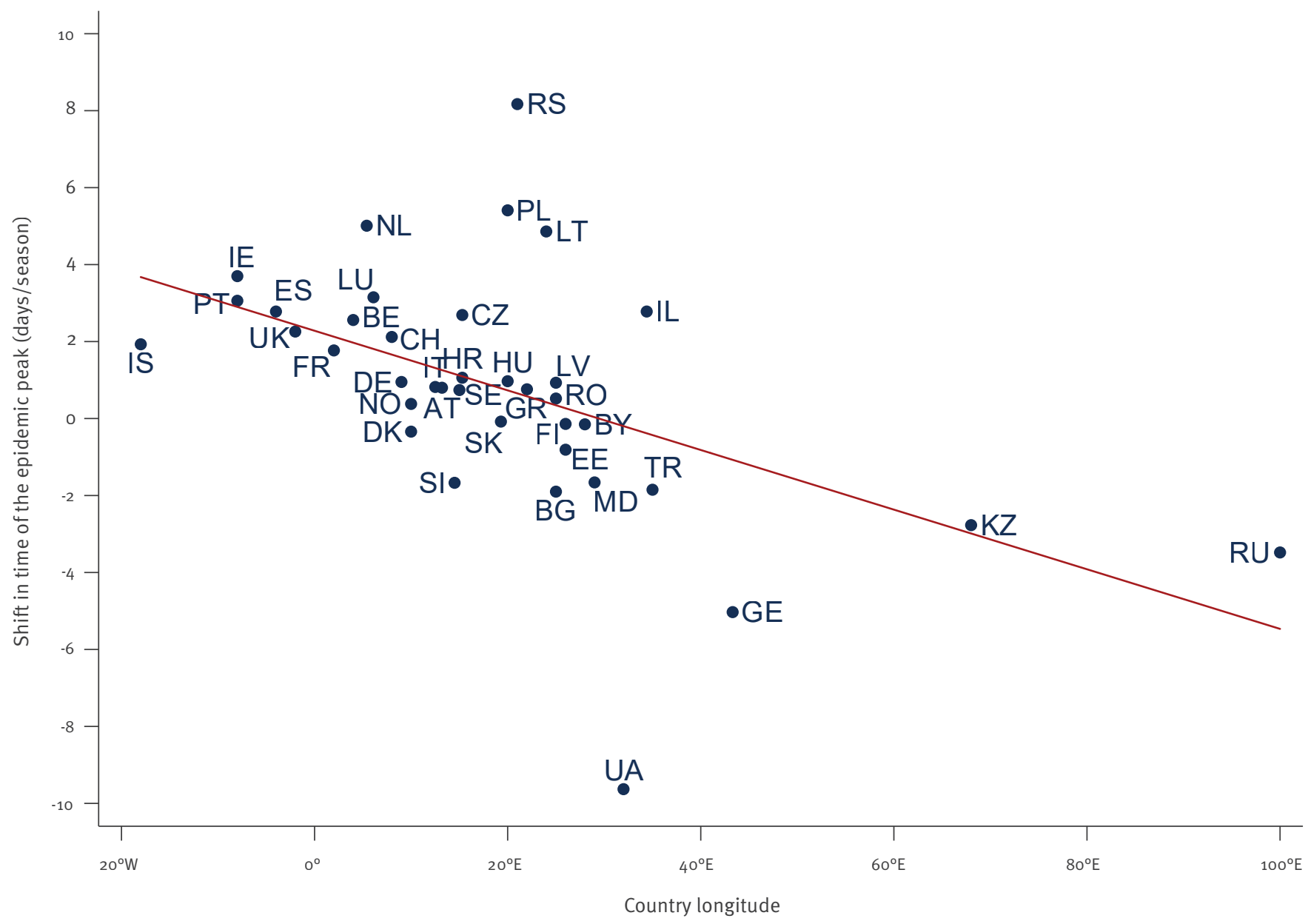

WHO: World Health Organization.

Source: WHO FluNet database [18] for July 1996 to June 2016. Data for July 2009 to June 2010 were excluded.

Country codes (ISO 3166-1 alpha-2): AT: Austria; BE: Belgium; BG: Bulgaria; BY: Belarus; CH: Switzerland; CZ: Czech Republic; DE: Germany; DK: Denmark; EE: Estonia; ES:Spain; FI: Finland; FR: France; GE: Georgia; GR: Greece; HR: Croatia; HU: Hungary; IE: Ireland; IL: Israel; IS: Iceland; IT: Italy; KZ: Kazakhstan; LT: Lithuania; LU: Luxembourg; LV: Latvia; MD: Moldova; NL: the Netherlands; NO: Norway; PL: Poland; PT: Portugal; RO: Romania; RS: Serbia; RU: Russian Federation; SE: Sweden; SI:Slovenia; SK: Slovakia; TR: Turkey; UA: Ukraine; UK: United Kingdom.

European Region changed in recent years, we defined the duration as the number of days between the epidemic peak in countries in the west and east of the WHO European Region, and used linear regression models to explore whether this varied with time. The countries selected for this analysis were countries that were situated at the western (Portugal and the United Kingdom (UK)) or eastern (Russian Federation) edges of the Region with data available for a large number of seasons (from 2004/05 to 2015/16). A beta coefficient above (below) zero means that the duration of influenza activity in the WHO European Region became progressively longer (shorter) each season during the study period.
All analyses were conducted using Stata version 14 (Stata Corp, College Station, TX). Maps were prepared using Map Chart (http://mapchart.net/). All statistical significance tests were two-sided and $p$ values $<0.05$ were considered significant.

\section{Sensitivity analysis}

The impact of very early or late epidemic peaks was assessed by excluding one season at a time from the analyses. The impact of geographical outliers was assessed by first identifying outliers and influential points (i.e. points that significantly influence the output of Model 2) using studentised residuals, Cook's $D$ and difference in fits (DFFITS) $[23,24]$ ) and then by excluding the identified countries from analyses. Finally, to assess the impact of removing countries 
TABLE 1

Geographical and demographic characteristics and data availability of countries in the included in the analysis, WHO European Region, July 1996-June 2016 ( $\mathrm{n}=38$ )

\begin{tabular}{|c|c|c|c|c|c|c|}
\hline Country & Latitude $^{\mathrm{a}}$ & Longitude $^{\mathrm{a}}$ & $\begin{array}{l}\text { Population } \\
\text { (millions) }^{\text {b }}\end{array}$ & $\begin{array}{c}\text { Number of } \\
\text { seasons with data }\end{array}$ & $\begin{array}{l}\text { Median number of influenza } \\
\text { cases per season }\end{array}$ & $\begin{array}{l}\text { Overall number of } \\
\text { influenza cases }\end{array}$ \\
\hline Austria & $47.2 \mathrm{~N}$ & $13.2 \mathrm{E}$ & 8.7 & 8 & 850 & 8,686 \\
\hline Belarus & $53.0 \mathrm{~N}$ & $28.0 \mathrm{E}$ & 9.6 & 5 & 546 & 3,869 \\
\hline Belgium & $50.5 \mathrm{~N}$ & $4.0 \mathrm{E}$ & 11.3 & 13 & 516 & 7,171 \\
\hline Bulgaria & $43.0 \mathrm{~N}$ & $25.0 \mathrm{E}$ & 7.2 & 5 & 321 & 1,526 \\
\hline Croatia & $45.1 \mathrm{~N}$ & $15.3 \mathrm{E}$ & 4.5 & 10 & 681 & 7,819 \\
\hline Czech Republic & $49.4 \mathrm{~N}$ & $15.3 \mathrm{E}$ & 10.6 & 11 & 233 & 4,215 \\
\hline Denmark & $56.0 \mathrm{~N}$ & $10.0 \mathrm{E}$ & 5.6 & 10 & 780 & 14,609 \\
\hline Estonia & $59.0 \mathrm{~N}$ & $26.0 \mathrm{E}$ & 1.3 & 6 & 618 & 3,789 \\
\hline Finland & $64.0 \mathrm{~N}$ & $26.0 \mathrm{E}$ & 5.5 & 19 & 291 & 7,894 \\
\hline France & $46.0 \mathrm{~N}$ & $2.0 \mathrm{E}$ & 66.6 & 18 & 2,347 & 74,566 \\
\hline Georgia & $42.0 \mathrm{~N}$ & $43.3 \mathrm{E}$ & 4.9 & 6 & 215 & 1,893 \\
\hline Germany & $51.0 \mathrm{~N}$ & $9.0 \mathrm{E}$ & 80.9 & 17 & 1,412 & 25,880 \\
\hline Greece & $39.0 \mathrm{~N}$ & $22.0 \mathrm{E}$ & 10.8 & 10 & 545 & 11,206 \\
\hline Hungary & $47.0 \mathrm{~N}$ & $20.0 \mathrm{E}$ & 9.9 & 6 & 459 & 2,670 \\
\hline Iceland & $65.0 \mathrm{~N}$ & $18.0 \mathrm{~W}$ & 0.3 & 8 & 148 & 1,485 \\
\hline Ireland & $53.0 \mathrm{~N}$ & $8.0 \mathrm{~W}$ & 4.9 & 9 & 1,564 & 10,629 \\
\hline Israel & $31.3 \mathrm{~N}$ & $34.4 \mathrm{E}$ & 8 & 11 & 763 & 8,837 \\
\hline Italy & $42.5 \mathrm{~N}$ & $12.5 \mathrm{E}$ & 61.9 & 17 & 571 & 17,227 \\
\hline Kazakhstan & $48.0 \mathrm{~N}$ & $68.0 \mathrm{E}$ & 18.2 & 7 & 598 & 3,461 \\
\hline Latvia & $57.0 \mathrm{~N}$ & $25.0 \mathrm{E}$ & 2 & 16 & 551 & 16,549 \\
\hline Lithuania & $56.0 \mathrm{~N}$ & $24.0 \mathrm{E}$ & 2.9 & 5 & 633 & 2,691 \\
\hline Luxembourg & $49.4 \mathrm{~N}$ & $6.1 \mathrm{E}$ & 0.6 & 7 & 421 & 2,654 \\
\hline Moldova & $47.0 \mathrm{~N}$ & $29.0 \mathrm{E}$ & 3.5 & 5 & 214 & 1,358 \\
\hline The Netherlands & $52.3 \mathrm{~N}$ & $5.4 \mathrm{E}$ & 16.9 & 7 & 1,033 & 12,097 \\
\hline Norway & $62.0 \mathrm{~N}$ & $10.0 \mathrm{E}$ & 5.2 & 17 & 1,127 & 68,249 \\
\hline Poland & $52.0 \mathrm{~N}$ & $20.0 \mathrm{E}$ & 38.6 & 6 & 1,088 & 7,555 \\
\hline Portugal & $39.3 \mathrm{~N}$ & $8.0 \mathrm{~W}$ & 10.8 & 17 & 303 & 8,956 \\
\hline Romania & $46.0 \mathrm{~N}$ & $25.0 \mathrm{E}$ & 21.7 & 14 & 335 & 5,729 \\
\hline Russian Federation & $60.0 \mathrm{~N}$ & $100.0 \mathrm{E}$ & 142.4 & 11 & 4,629 & 79,376 \\
\hline Serbia & $44.0 \mathrm{~N}$ & $21.0 \mathrm{E}$ & 7.2 & 6 & 334 & 1,809 \\
\hline Slovakia & $48.4 \mathrm{~N}$ & $19.3 \mathrm{E}$ & 5.4 & 5 & 279 & 1,657 \\
\hline Slovenia & $46.1 \mathrm{~N}$ & $14.5 \mathrm{E}$ & 2 & 13 & 425 & 6,924 \\
\hline Spain & $40.0 \mathrm{~N}$ & $4.0 \mathrm{~W}$ & 48.1 & 11 & 4,697 & 41,185 \\
\hline Sweden & $62.0 \mathrm{~N}$ & $15.0 \mathrm{E}$ & 9.8 & 15 & 2,452 & 57,236 \\
\hline Switzerland & $47.0 \mathrm{~N}$ & $8.0 \mathrm{E}$ & 8.1 & 19 & 361 & 20,771 \\
\hline Turkey & $39.0 \mathrm{~N}$ & $35.0 \mathrm{E}$ & 79.4 & 7 & 1,056 & 14,725 \\
\hline Ukraine & $49.0 \mathrm{~N}$ & $32.0 \mathrm{E}$ & 44.4 & 6 & 620 & 6,586 \\
\hline United Kingdom & $54.0 \mathrm{~N}$ & $2.0 \mathrm{~W}$ & 64.1 & 17 & 1,079 & 61,507 \\
\hline
\end{tabular}

E: east; N: north; S: south; W: west; WHO: World Health Organization.

Source: WHO FluNet database [18] for July 1996 to June 2016. Data from July 2009 to June 2010 were excluded.

${ }^{\text {a }}$ Latitude and longitude are for the centroid or centre point of the country.

${ }^{\mathrm{b}}$ Most recent estimates [35].

with limited data, all analyses were repeated excluding countries that had data for less than seven or less than 10 seasons (the basic analysis already excluded countries with less than five seasons, see above).

In order to test the robustness of results, all analyses were repeated using the 3-week moving average of the positive detection rate (defined as the ratio of the number of reported cases over the number of respiratory specimens processed in the same week) instead of the 3-week moving average of the number of reported cases.

\section{Results}

The initial dataset included 819,332 influenza cases from 676 seasons in 49 countries of the WHO European Region; no data were available for Andorra, Cyprus, Monaco and San Marino. After applying the exclusion 
TABLE 2

Temporal shift of the influenza epidemic peak in countries of the WHO European Region, July 1996-June 2016 (n = 38)

\begin{tabular}{|c|c|c|c|c|c|c|c|}
\hline \multirow{2}{*}{ Country } & \multirow{2}{*}{ Latitude $^{\mathrm{a}}$} & \multirow{2}{*}{ Longitude $^{\mathrm{a}}$} & \multirow{2}{*}{$\begin{array}{c}\text { Number of seasons } \\
\text { with data }\end{array}$} & \multicolumn{4}{|c|}{ Temporal shift of the epidemic peak (days/season) } \\
\hline & & & & beta $^{b}$ & $95 \% \mathrm{Cl}$ & $\mathrm{p}$ value & R2 \\
\hline Austria & $47.2 \mathrm{~N}$ & $13.2 \mathrm{E}$ & 8 & 0.80 & -2.19 to 3.79 & 0.539 & $6.6 \%$ \\
\hline Belarus & $53.0 \mathrm{~N}$ & $28.0 \mathrm{E}$ & 5 & -0.15 & -21.88 to 21.58 & 0.984 & $0.0 \%$ \\
\hline Belgium & $50.5 \mathrm{~N}$ & $4.0 \mathrm{E}$ & 13 & 2.56 & 0.09 to 5.04 & 0.044 & $32.0 \%$ \\
\hline Bulgaria & $43.0 \mathrm{~N}$ & $25.0 \mathrm{E}$ & 5 & -1.90 & -14.67 to 10.87 & 0.668 & $7.0 \%$ \\
\hline Croatia & $45.1 \mathrm{~N}$ & $15.3 \mathrm{E}$ & 10 & 1.06 & -2.62 to 4.73 & 0.526 & $5.2 \%$ \\
\hline Czech Republic & $49.4 \mathrm{~N}$ & $15.3 \mathrm{E}$ & 11 & 2.69 & 0.36 to 5.03 & 0.028 & $43.0 \%$ \\
\hline Denmark & $56.0 \mathrm{~N}$ & $10.0 \mathrm{E}$ & 10 & -0.34 & -4.65 to 3.97 & 0.861 & $0.4 \%$ \\
\hline Estonia & $59.0 \mathrm{~N}$ & $26.0 \mathrm{E}$ & 6 & -0.81 & -9.66 to 8.03 & 0.811 & $1.6 \%$ \\
\hline Finland & $64.0 \mathrm{~N}$ & $26.0 \mathrm{E}$ & 19 & -0.14 & -2.04 to 1.75 & 0.874 & $0.2 \%$ \\
\hline France & $46.0 \mathrm{~N}$ & $2.0 \mathrm{E}$ & 18 & 1.77 & -0.08 to 3.61 & 0.059 & $20.5 \%$ \\
\hline Georgia & $42.0 \mathrm{~N}$ & $43.3 \mathrm{E}$ & 6 & -5.03 & -13.9 to 3.84 & 0.191 & $38.2 \%$ \\
\hline Germany & $51.0 \mathrm{~N}$ & $9.0 \mathrm{E}$ & 17 & 0.95 & -0.74 to 2.64 & 0.248 & $8.8 \%$ \\
\hline Greece & $39.0 \mathrm{~N}$ & $22.0 \mathrm{E}$ & 10 & 0.76 & -2.91 to 4.43 & 0.645 & $2.8 \%$ \\
\hline Hungary & $47.0 \mathrm{~N}$ & $20.0 \mathrm{E}$ & 6 & 0.97 & -8.02 to 9.97 & 0.779 & $2.2 \%$ \\
\hline Iceland & $65.0 \mathrm{~N}$ & $18.0 \mathrm{~W}$ & 8 & 1.93 & -1.23 to 5.08 & 0.186 & $27.1 \%$ \\
\hline Ireland & $53.0 \mathrm{~N}$ & $8.0 \mathrm{~W}$ & 9 & 3.70 & -2.07 to 9.48 & 0.173 & $24.7 \%$ \\
\hline Israel & $31.3 \mathrm{~N}$ & $34.4 \mathrm{E}$ & 11 & 2.78 & -0.85 to 6.42 & 0.117 & $25.0 \%$ \\
\hline Italy & $42.5 \mathrm{~N}$ & $12.5 \mathrm{E}$ & 17 & 0.82 & -0.76 to 2.40 & 0.288 & $7.5 \%$ \\
\hline Kazakhstan & $48.0 \mathrm{~N}$ & $68.0 \mathrm{E}$ & 7 & -2.77 & -7.19 to 1.66 & 0.169 & $34.0 \%$ \\
\hline Latvia & $57.0 \mathrm{~N}$ & $25.0 \mathrm{E}$ & 16 & 0.93 & -1.59 to 3.45 & 0.443 & $4.3 \%$ \\
\hline Lithuania & $56.0 \mathrm{~N}$ & $24.0 \mathrm{E}$ & 5 & 4.86 & -15.01 to 24.74 & 0.493 & $16.8 \%$ \\
\hline Luxembourg & $49.4 \mathrm{~N}$ & $6.1 \mathrm{E}$ & 7 & 3.15 & -1.70 to 7.99 & 0.156 & $35.8 \%$ \\
\hline Moldova & $47.0 \mathrm{~N}$ & $29.0 \mathrm{E}$ & 5 & -1.66 & -6.25 to 2.93 & 0.333 & $30.7 \%$ \\
\hline The Netherlands & $52.3 \mathrm{~N}$ & $5.4 \mathrm{E}$ & 7 & 5.01 & -3.99 to 14.01 & 0.212 & $29.0 \%$ \\
\hline Norway & $62.0 \mathrm{~N}$ & $10.0 \mathrm{E}$ & 17 & 0.38 & -2.22 to 2.99 & 0.758 & $0.7 \%$ \\
\hline Poland & $52.0 \mathrm{~N}$ & $20.0 \mathrm{E}$ & 6 & 5.41 & -3.30 to 14.12 & 0.160 & $42.7 \%$ \\
\hline Portugal & $39.3 \mathrm{~N}$ & $8.0 \mathrm{~W}$ & 17 & 3.06 & 0.61 to 5.51 & 0.018 & $32.1 \%$ \\
\hline Romania & $46.0 \mathrm{~N}$ & $25.0 \mathrm{E}$ & 14 & 0.52 & -2.69 to 3.74 & 0.729 & $1.0 \%$ \\
\hline Russian Federation & $60.0 \mathrm{~N}$ & $100.0 \mathrm{E}$ & 11 & -3.48 & -6.58 to -0.38 & 0.032 & $41.8 \%$ \\
\hline Serbia & $44.0 \mathrm{~N}$ & $21.0 \mathrm{E}$ & 6 & 8.17 & -3.15 to 19.50 & 0.116 & $50.1 \%$ \\
\hline Slovakia & $48.4 \mathrm{~N}$ & $19.3 \mathrm{E}$ & 5 & -0.08 & -0.62 to 0.46 & 0.654 & $7.6 \%$ \\
\hline Slovenia & $46.1 \mathrm{~N}$ & $14.5 \mathrm{E}$ & 13 & -1.67 & -4.48 to 1.15 & 0.219 & $13.4 \%$ \\
\hline Spain & $40.0 \mathrm{~N}$ & $4.0 \mathrm{~W}$ & 11 & 2.78 & 0.30 to 5.26 & 0.032 & $41.7 \%$ \\
\hline Sweden & $62.0 \mathrm{~N}$ & $15.0 \mathrm{E}$ & 15 & 0.74 & -1.79 to 3.26 & 0.540 & $3.0 \%$ \\
\hline Switzerland & $47.0 \mathrm{~N}$ & $8.0 \mathrm{E}$ & 19 & 2.12 & 0.26 to 3.98 & 0.028 & $25.4 \%$ \\
\hline Turkey & $39.0 \mathrm{~N}$ & $35.0 \mathrm{E}$ & 7 & -1.85 & -15.66 to 11.96 & 0.745 & $2.3 \%$ \\
\hline Ukraine & $49.0 \mathrm{~N}$ & $32.0 \mathrm{E}$ & 6 & -9.63 & -17.68 to -1.58 & 0.029 & $73.4 \%$ \\
\hline United Kingdom & $54.0 \mathrm{~N}$ & $2.0 \mathrm{~W}$ & 17 & 2.26 & -0.80 to 5.32 & 0.136 & $14.2 \%$ \\
\hline
\end{tabular}

$\mathrm{Cl}$ : confidence interval; E: east; N: north; S: south; W: west; WHO: World Health Organization.

Source: WHO FluNet database [18] for July 1996 to June 2016. Data from July 2009 to June 2010 were excluded.

a Latitude and longitude are for the centroid or centre point of the country.

${ }^{b}$ Obtained from country-specific linear regression models using the season as independent variable and of the peak of the influenza epidemic (day of the year; see text for definition) as dependent variable. A value of the beta coefficient above (below) zero means that the peak occurred progressively later (earlier) each season during the study period.

criteria, the final dataset used for the analysis included 635,046 influenza cases from 400 seasons in 38 countries (Table 1). The median number of seasons per country was 10 and ranged from five (Belarus, Bulgaria, Lithuania, Moldova and Slovakia) to 19 (Finland and Switzerland). The median number of influenza cases reported per season was 601 (interquartile range: 267-1,414).

Timing of the influenza epidemic peak The peak of the influenza epidemics occurred progressively later during the study period in 25 countries 
TABLE 3

Relationship between the temporal shift of the influenza epidemic peak and a country's longitude, and results of sensitivity analysis, WHO European Region, July 1996-June 2016 ( $\mathrm{n}=38$ )

\begin{tabular}{|c|c|c|c|c|}
\hline Dependent variable & \multicolumn{4}{|c|}{ Temporal shift of the influenza epidemic peak (days/season) } \\
\hline Independent variable & \multicolumn{4}{|c|}{ Country longitude ${ }^{\mathrm{a}}$} \\
\hline Model output & beta $^{b}$ & $95 \% \mathrm{Cl}$ & $\mathrm{p}$ value & $\mathrm{R}^{2}$ \\
\hline All countries included $(n=38)$ & 0.077 & 0.034 to 0.121 & 0.001 & $26.6 \%$ \\
\hline \multirow{2}{*}{ One season removed at a time (range) } & 0.056 & 0.018 to 0.095 & 0.005 & $24.0 \%$ \\
\hline & 0.091 & 0.037 to 0.145 & 0.002 & $27.0 \%$ \\
\hline Countries with $\geq 7$ seasons of data $(n=27)$ & 0.062 & 0.039 to 0.085 & $<0.001$ & $53.5 \%$ \\
\hline Countries with $\geq 10$ seasons of data $(n=20)$ & 0.052 & 0.026 to 0.077 & $<0.001$ & $50.5 \%$ \\
\hline Outliers & \multicolumn{4}{|c|}{ Serbia, Ukraine } \\
\hline All countries except outliers & 0.071 & 0.040 to 0.100 & $<0.001$ & $40.3 \%$ \\
\hline Influential points & \multicolumn{4}{|c|}{ Serbia, Ukraine, Georgia, Russian Federation } \\
\hline All countries except influential points & 0.063 & 0.035 to 0.092 & $<0.001$ & $38.5 \%$ \\
\hline
\end{tabular}

$\mathrm{Cl}$ : confidence interval; WHO: World Health Organization.

Source: WHO FluNet database [18] for July 1996 to June 2016. Data from July 2009 to June 2010 were excluded.

a Latitude and longitude are for the centroid or (if not available) the centre point of each country.

${ }^{b}$ A beta coefficient above (below) zero means that the temporal shift of the influenza peak was greater (smaller) by moving from east to west.

(Figure 1 and Table 2). The trend was statistically significant in Belgium, the Czech Republic, Portugal, Spain and Switzerland. In 13 other European countries, the influenza epidemic occurred progressively earlier, with a statistically significant trend in the Russian Federation and Ukraine.

Linear regression analysis indicated a statistically significant longitudinal gradient for the temporal shift of the epidemic peak in the WHO European Region (beta $=0.077 ; 95 \% \mathrm{Cl}: 0.034-0.121 ; \mathrm{p}=0.001$; $\mathrm{R}^{2}=26.6 \%$ ) (Table 3 ).

The peak of the epidemic occurred on average 2.28 days later every season at longitude $0^{\circ}$ (95\% Cl: $1.07-$ 3.49; $p=0.001$ ), was stable over time at longitude ca $30^{\circ} \mathrm{E}$, and occurred earlier every season at more eastern longitudes (by 2.37 days at $60^{\circ} \mathrm{E}$ ) (Figure 2).

\section{Duration of influenza activity in the WHO European region}

The distance in time between the influenza epidemic peak in Portugal and in the Russian Federation decreased by an average 4.42 days per season during the study period (95\% Cl: 0.49-9.33; $\mathrm{p}=0.072$; $\mathrm{R}^{2}=31.6 \%$ ). In the comparison between the UK and the Russian Federation, the decrease was 5.99 days per season (95\% Cl: 0.41-11.56; $p=0.038 ; \mathrm{R}^{2}=39.6 \%$ ).

\section{Sensitivity analyses}

The analysis using the positive detection rate instead of the reported number of laboratory-confirmed influenza cases in Model 1 and Model 2 yielded similar results. The existence of a longitudinal gradient was confirmed using this alternative approach (beta $=0.093 ; 95 \% \mathrm{Cl}$ : $0.023-0.163 ; p=0.010$ ), although a smaller proportion of the variability between countries was explained by the country longitude $\left(R^{2}=16.9 \%\right)$. Using this alternative approach, the annual delay of the epidemic peak was 2.93 days at longitude $0^{\circ}(95 \% \mathrm{Cl}: 1.03-4.92$; $\mathrm{p}=0.004)$ and was null at longitude $\mathrm{ca} 30^{\circ} \mathrm{E}$.

The 'leave-one-out' sensitivity analysis confirmed the presence of a longitudinal gradient. The beta coefficient varied between 0.056 (95\% Cl: 0.018-0.095; $\left.\mathrm{p}=0.005 ; \mathrm{R}^{2}=22.4 \%\right)$ when the $2015 / 16$ season was excluded and 0.091 (95\% Cl: 0.037-0.145; $\mathrm{p}=0.002$; $\mathrm{R}^{2}=27.0 \%$ ) when the $2010 / 11$ season was excluded (Table 3). Serbia and Ukraine were identified as outliers and as influential points, and Georgia and the Russian Federation were identified as influential points. Results were similar when these countries and when countries with limited data were excluded (Table 3).

\section{Discussion}

This study showed that a key characteristic of seasonal influenza epidemics - the timing of the peak - has changed in the WHO European Region between 1996 and 2016. Unexpectedly, however, the timing of the peak did not change uniformly across the Region, but instead according to a longitudinal gradient, with influenza epidemics tending to peak progressively later in Western European countries and progressively earlier in Eastern European countries. These results were confirmed in several sensitivity analyses.

Our findings have implications for influenza control and prevention in countries across the WHO European Region. The implementation of vaccination campaigns should be synchronised with the timing of influenza epidemics, considering that the optimal immune response to vaccination may take 2 to 4 weeks to develop [16] 
and may decline substantially within 6 months [17]. Accordingly, failure to consider a systematic shift in the timing of epidemics (i.e. the timing of their onset, peak and end) may gradually reduce the effectiveness of influenza vaccination programmes. Influenza vaccination campaigns may need to be planned later in Western Europe and earlier in Eastern Europe, especially if the observed trends persist in the coming years. Importantly, we observed exceptions to these general patterns, and each country needs to carefully assess their situation at a national level, i.e. verify that the current timing of vaccination campaigns is still optimal. For example, the peak in Denmark, which is considered to be a country in Western Europe, has remained fairly stable over the years, and this would suggest that the timing of the vaccination campaign may not need to be modified.

One important consequence of these changes is that the overall duration of influenza activity in the WHO European Region (as a whole) has shortened over the past twenty years, with the average interval between peak influenza activity in western and eastern countries declining from nearly 2 months in 2004/05 (with influenza activity first peaking in the west and then in the east) to less than 3 weeks in 2015/16 (with peaks typically occurring in February and March in most countries [25]). Our findings are particularly relevant for influenza vaccination programmes, as they suggest that the timing of epidemics and, therefore, the optimal time of vaccination has become better aligned across the whole WHO European Region, which in turn allows more coordinated and efficient management of surveillance and prevention efforts.

Changes in national surveillance systems may lead to changes in some metrics of influenza epidemics, such as their duration (e.g. influenza surveillance limited to the period 'week 40 to week 20' vs year-round surveillance) and intensity (e.g. following changes in the definitions for influenza-like illness and acute respiratory syndrome). However, the timing of the epidemic peak is less sensitive to how an influenza surveillance system is structured, and we are confident that our findings are not an artefact but the description of an actual phenomenon. Although we found that the timing of the peak of seasonal influenza epidemics in Europe is changing, we did not investigate the possible causes of this change. As mentioned in the introduction, the temporal characteristics (e.g. timing and synchrony between countries) of influenza epidemics are influenced by several factors, including patterns of population mobility such as air travel and commuting $[7,26]$ (especially in countries in Eastern European countries) and climatic and meteorological parameters (such as humidity, temperature and rainfalls) [8-10,12]. For instance, Towers et al. noted a systematic change in the timing of seasonal influenza epidemics in the United States from 1997 to 2013, with warm winters that tended to be followed by severe epidemics with early onset and peak in the following year [27].
However, it is unclear why there is an opposite trend in the timing of influenza epidemic peaks in Western and Eastern Europe, as the above factors are unlikely to have affected Western and Eastern Europe in different ways.

Our findings raise many questions and call for a number of follow-up investigations. Integrating climatic and meteorological time series with influenza surveillance data would help confirm the hypothesis that the changes in the timing of influenza epidemics are due to climate change or develop alternative explanations. The analysis performed here could be extended to earlier seasons to assess when the temporal trends started, to other areas of the world to determine whether similar changes in timing are taking place elsewhere (e.g. North America), and to other aspects of influenza epidemiology to look for other changes (for instance the duration of epidemics). Findings from these additional investigations would help predict future scenarios for influenza epidemiology and would help health authorities take appropriate measures to mitigate the public health consequences of seasonal epidemics. Furthermore, this research approach could be expanded to include other viral respiratory infections such as respiratory syncytial virus $[28,29]$ and other seasonal illnesses such as gastrointestinal infections [30] or even non-infectious diseases like asthma $[31,32]$.

The results of this study are strengthened by the availability of influenza surveillance data for a large number of countries and for an extended period, by the use of straightforward statistical methods and the robustness of results across a range of sensitivity analyses. However, the results should be considered in the light of certain limitations. Although influenza surveillance capacity has improved globally since the 2009 pandemic [33], differences in influenza data collection and reporting remain between countries [34] and for some countries, low data quality may have been an issue. Also, the lack of data stratified by region for the Russian Federation prevented us from assessing whether the longitudinal gradient for the temporal shift of the epidemic peak extends to its Pacific coast or attenuates (or inverts) at some longitude. Furthermore, data were available for only one country in the Caucasus (Georgia) and central Asia (Kazakhstan), which limits our ability to extrapolate the results to these areas. Finally, data were available for only a few (five or six) influenza seasons for 11 countries of the WHO European Region, which may have caused instability in the analysis (i.e. coefficients in Model 1), although the presence of geographical gradients was confirmed in all sensitivity analyses.

\section{Conclusion}

We found that the timing of the peak of influenza epidemics has changed in countries of the WHO European Region between 1996 and 2016. The main drivers behind this phenomenon remain to be clarified, but 
how the changes might affect influenza prevention and control efforts in Europe demands further attention.

\section{Acknowledgements}

We would like to thank EU/EEA member states' laboratories reporting their influenza surveillance data to The European Surveillance System (TESSy) database, hosted at the European Centre for Disease Prevention and Control (ECDC), from which data are shared with the global WHO FluNet database. Dr Phillip Leventhal (4Clinics, Paris, France) provided scientific editing, which was paid for by Sanofi Pasteur.

Source of funding: The study is supported by a research grant by Sanofi Pasteur: the 'Global Epidemiology of Influenza B' research project.

\section{Conflict of interest}

None declared.

\section{Authors' contributions}

SC, JP, CEGS and FS conceived the study. SC performed the statistical analysis. SC and JP interpreted the results and wrote the first draft of the manuscript. All authors critically revised the manuscript and approved its final version.

\section{References}

1. Saker L, Lee K, Cannito B, Gilmore A, Campbell-Lendrum DQ. Globalization and infectious diseases: a review of the linkages. Social, Economic and Behavioural Research. Special topics no. 3. Geneva: World Health Organization; 2004. Available from: http://www.who.int/tdr/publications/documents/seb_topic3. pdf

2. Githeko AK, Lindsay SW, Confalonieri UE, Patz JA. Climate change and vector-borne diseases: a regional analysis. Bull World Health Organ. 2000;78(9):1136-47. PMID: 11019462

3. Bai L, Morton LC, Liu Q. Climate change and mosquito-borne diseases in China: a review. Global Health. 2013;9(1):10. https://doi.org/10.1186/1744-8603-9-10 PMID: 23497420

4. Negev M, Paz S, Clermont A, Pri-Or NG, Shalom U, Yeger T, et al. Impacts of climate change on vector borne diseases in the Mediterranean basin - Implications for preparedness and adaptation policy. Int J Environ Res Public Health. 2015;12(6):6745-70. https://doi.org/10.3390/ijerph120606745 PMID: 26084000

5. Semenza JC, Herbst S, Rechenburg A, Suk JE, Höser C, Schreiber C, et al. Climate change impact assessment of food- and waterborne diseases. Crit Rev Environ Sci Technol. 2012;42(8):857-90. https://doi.org/10.1080/10643389.2010.53 4706 PMID: 24808720

6. Levy K, Woster AP, Goldstein RS, Carlton EJ. Untangling the impacts of climate change on waterborne diseases: a systematic review of relationships between diarrheal diseases and temperature, rainfall, flooding, and drought. Environ Sci Technol. 2016;50(10):4905-22. https://doi.org/10.1021/acs. est.5bo6186 PMID: 27058059

7. Viboud C, Bjørnstad ON, Smith DL, Simonsen L, Miller MA Grenfell BT. Synchrony, waves, and spatial hierarchies in the spread of influenza. Science. 2006;312(5772):447-51. https:// doi.org/10.1126/science.1125237 PMID: 16574822

8. Tamerius JD, Shaman J, Alonso WJ, Bloom-Feshbach K, Uejio CK, Comrie A, et al. Environmental predictors of seasonal influenza epidemics across temperate and tropical climates. PLoS Pathog. 2013;9(3):e1003194. https://doi.org/10.1371/ journal.ppat.1003194 PMID: 23505366

9. Tang JW, Lai FY, Nymadawa P, Deng YM, Ratnamohan M, Petric $M$, et al. Comparison of the incidence of influenza in relation to climate factors during 2000-2007 in five countries. J Med Virol. 2010;82(11):1958-65. https://doi.org/10.1002/jmv.21892 PMID: 20872724
10. Soebiyanto RP, Adimi F, Kiang RK. Modeling and predicting seasonal influenza transmission in warm regions using climatological parameters. PLoS One. 2010;5(3):e9450. https://doi.org/10.1371/journal.pone.0009450 PMID: 20209164

11. Charaudeau S, Pakdaman K, Boëlle PY. Commuter mobility and the spread of infectious diseases: application to influenza in France. PLoS One. 2014;9(1):e83002. https://doi.org/10.1371/ journal.pone.0083002 PMID: 24416152

12. Soebiyanto RP, Gross D, Jorgensen P, Buda S, Bromberg $M$, Kaufman Z, et al. Associations between meteorological parameters and influenza activity in Berlin (Germany), Ljubljana (Slovenia), Castile and León (Spain) and Israel districts. PLoS One. 2015;10(8):e0134701. https://doi. org/10.1371/journal.pone.0134701 PMID: 26309214

13. Weinberger DM, Krause TG, Mølbak K, Cliff A, Briem H, Viboud $C$, et al. Influenza epidemics in Iceland over 9 decades: changes in timing and synchrony with the United States and Europe. Am J Epidemiol. 2012;176(7):649-55. https://doi. org/10.1093/aje/kwS140 PMID: 22962250

14. Tan Y, Lam TT, Wu C, Lee SS, Viboud C, Zhang R, et al. Increasing similarity in the dynamics of influenza in two adjacent subtropical Chinese cities following the relaxation of border restrictions. J Gen Virol. 2014;95(Pt 3):531-8. https:// doi.org/10.1099/vir.0.059998-o PMID: 24310518

15. Caini S, Andrade W, Badur S, Balmaseda A, Barakat A, Bella $A$, et al. Temporal patterns of influenza $A$ and $B$ in tropical and temperate countries: what are the lessons for influenza vaccination? PLoS One. 2016;11(3):e0152310. https://doi. org/10.1371/journal.pone.0152310 PMID: 27031105

16. Fiore $A E$, Bridges $C B$, Cox NJ. Seasonal influenza vaccines. Curr Top Microbiol Immunol. 2009;333:43-82. https://doi. org/10.1007/978-3-540-92165-3_3 PMID: 19768400

17. Kissling E, Nunes B, Robertson C, Valenciano M, Reuss A, Larrauri A, et al. I-MOVE multicentre case-control study $2010 / 11$ to $2014 / 15$ : Is there within-season waning of influenza type/subtype vaccine effectiveness with increasing time since vaccination? Euro Surveill. 2016;21(16):30201. https://doi. org/10.2807/1560-7917.ES.2016.21.16.30201 PMID: 27124420

18. World Health Organization (WHO). FluNet. Geneva: WHO. [Accessed: 6 November 2016]. Available from: http://www.who. int/influenza/gisrs_laboratory/flunet/en/

19. World Health Organization (WHO). Regional Office for Europe: Countries. Geneva: WHO. [Accessed: 8 November 2016]. Available from: http://www.euro.who.int/en/countries

20. van Asten L, Bijkerk P, Fanoy E, van Ginkel A, Suijkerbuijk $A$, van der Hoek W, et al. Early occurrence of influenza $A$ epidemics coincided with changes in occurrence of other respiratory virus infections. Influenza Other Respi Viruses. 2016;10(1):14-26. https://doi.org/10.1111/irv.12348 PMID: 26369646

21. Central Intelligence Agency (CIA). The World Factbook. Country comparison: geographic coordinates. Washington: CIA. [Accessed: 8 November 2016]. Available from: https://www.cia. gov/library/publications/the-world-factbook/fields/2011.html

22. Paget J, Marquet R, Meijer A, van der Velden K. Influenza activity in Europe during eight seasons (1999-2007): an evaluation of the indicators used to measure activity and an assessment of the timing, length and course of peak activity (spread) across Europe. BMC Infect Dis. 2007;7(7):141. https:// doi.org/10.1186/1471-2334-7-141 PMID: 18047685

23. Belsley DA, Kuh E, Welsh RE. Regression diagnostics: identifying influential data and sources of collinearity. Wiley series in probability and mathematical statistics. New York: John Wiley \& Sons; 2005 . Available from: http://onlinelibrary. wiley.com/book/10.1002/0471725153

24. Stevens JP. Outliers and influential data points in regression analysis. Psychol Bull. 1984;95(2):334-44. https://doi. org/10.1037/0033-2909.95.2.334

25. Caini S, Alonso WJ, Séblain CE, Schellevis F, Paget J. The spatiotemporal characteristics of influenza A and B in the WHO European Region: can one define influenza transmission zones in Europe? Euro Surveill. 2017;22(35):30606. https://doi. org/10.2807/1560-7917.ES.2017.22.35.30606 PMID: 28877844

26. Grais RF, Ellis JH, Kress A, Glass GE. Modeling the spread of annual influenza epidemics in the U.S.: the potential role of air travel. Health Care Manage Sci. 2004;7(2):127-34. https://doi. org/10.1023/B:HCMS.0000020652.38181.da PMID: 15152977

27. Towers S, Chowell G, Hameed R, Jastrebski M, Khan M, Meeks J, et al. Climate change and influenza: the likelihood of early and severe influenza seasons following warmer than average winters. PLoS Curr. 2013;5:ecurrents.flu.3679b56a3a5313dc7co 43fb944c6f138. PMID: 24045424

28. Bloom-Feshbach K, Alonso WJ, Charu V, Tamerius J, Simonsen L, Miller MA, et al. Latitudinal variations in seasonal activity of influenza and respiratory syncytial virus (RSV): a global 
comparative review. PLoS One. 2013;8(2):e54445. https://doi. org/10.1371/journal.pone.0054445 PMID: 23457451

29. Pitzer VE, Viboud C, Alonso WJ, Wilcox T, Metcalf CJ, Steiner $C A$, et al. Environmental drivers of the spatiotemporal dynamics of respiratory syncytial virus in the United States PLoS Pathog. 2015;11(1):e1004591. https://doi.org/10.1371/ journal.ppat.1004591 PMID: 25569275

30. Fisman D. Seasonality of viral infections: mechanisms and unknowns. Clin Microbiol Infect. 2012;18(10):946-54. https://

doi.org/10.1111/j.1469-0691.2012.03968.x PMID: 22817528
Chen CH, Xirasagar S, Lin HC. Seasonality in adult asthma admissions, air pollutant levels, and climate: a populationbased study. J Asthma. 2006;43(4):287-92. https://doi. org/10.1080/02770900600622935 PMID: 16809242

32. Altzibar JM, Tamayo-Uria I, De Castro V, Aginagalde X, Albizu MV, Lertxundi A, et al. Epidemiology of asthma exacerbations and their relation with environmental factors in the Basque Country. Clin Exp Allergy. 2015;45(6):1099-108. https://doi. org/10.1111/cea.12419 PMID: 25258133

33. Polansky LS, Outin-Blenman S, Moen AC. Improved Global Capacity for Influenza Surveillance. Emerg Infect Dis. 2016;22(6):993-1001. https://doi.org/10.3201/eid2206.151521 PMID: 27192395

34. World Health Organization (WHO). Global epidemiological surveillance standards for influenza. Geneva: WHO; 2013. Available from: http://www.who.int/influenza/resources/ documents/WHO_Epidemiological_Influenza_Surveillance_ Standards_2014.pdf

35. Central Intelligence Agency (CIA). The World Factbook. Country comparison: population. Washington: CIA. [Accessed: 8 November 2016]. Available from: https://www.cia.gov/library/ publications/the-world-factbook/rankorder/2119rank.html

\section{License and copyright}

This is an open-access article distributed under the terms of the Creative Commons Attribution (CC BY 4.0) Licence. You may share and adapt the material, but must give appropriate credit to the source, provide a link to the licence, and indicate if changes were made.

This article is copyright of the authors, 2018. 